\title{
A search for mixotrophy and mucus trap production in Alexandrium spp. and the dynamics of mucus trap formation in Alexandrium pseudogonyaulax
}

\author{
Hannah E. Blossom ${ }^{\mathrm{a}, *}$, Tine Dencker Bædkel ${ }^{\mathrm{a}}$, Urban Tillmann ${ }^{\mathrm{b}}$, Per Juel Hansen ${ }^{\mathrm{a}}$ \\ a Marine Biological Section, University of Copenhagen, Strandpromenaden 5, 3000, Helsingør, Denmark \\ ${ }^{\mathrm{b}}$ Alfred-Wegener Institute for Polar and Marine Research, Chemical Ecology, Am Handelshafen 12, Bremerhaven, 27570, Germany
}

\section{A R T I C L E I N F O}

\section{Article history:}

Received 6 January 2017

Received in revised form 15 March 2017

Accepted 17 March 2017

Available online $\mathrm{xxx}$

\section{Keywords:}

Alexandrium pseudogonyaulax

Alexandrium spp.

Mixotrophy

Mucus trap

Phagotrophy

\section{A B S T R A C T}

Recently, a hitherto unknown feeding strategy, the toxic mucus trap, was discovered in the dinoflagellate Alexandrium pseudogonyaulax. In this study, over 40 strains of 8 different Alexandrium species (A. ostenfeldii, A. tamarense, A. catenella, A. taylorii, A. margalefii, A. hiranoi, A. insuetum and A. pseudogonyaulax) were screened for their ability to ingest prey and/or to form mucus traps. The mucus trap feeding strategy, where a mucus trap is towed by the longitudinal flagellum remains unique to $A$. pseudogonyaulax. In additional experiments, details of the trap were examined and quantified, such as speed and frequency of trap formation as well as what happens to the trap after the A. pseudogonyaulax cell detaches from it. The percentage of $A$. pseudogonyaulax cells producing a mucus trap and the number of prey cells caught increased with increasing prey concentration, whereas the physical size of the traps was independent of prey concentration. In one strain given an excess of prey, within $1 \mathrm{~h}$ over $90 \%$ of individual A. pseudogonyaulax cells had formed a trap, each containing an average of 45 prey cells. Individual $A$. pseudogonyaulax cells steadily produced traps and up to 5 traps were produced by a single $A$. pseudogonyaulax cell after only $24 \mathrm{~h}$. The attachment of an A. pseudogonyaulax cell to the trap only ceased during, and just following, cell division. Prey cells were, to some extent, capable of escaping from the mucus trap, but the trap remained sticky and continued catching prey for up to $48 \mathrm{~h}$ after the trap had been abandoned by the A. pseudogonyaulax cell. These results reveal that the effects of the mucus trap extend far beyond the removal of prey through ingestion, and the potential impact of this strategy on surrounding cells is high.

(C) 2017 Elsevier B.V. All rights reserved.

\section{Introduction}

Harmful algal blooms (HABs) are worldwide phenomena that represent an increasing threat to shellfish industries, recreational activities and marine environments (Hallegraeff, 1993; Burkholder et al., 2008; Anderson et al., 2012). Species from the genus Alexandrium are responsible for many of the most severe episodes, as they are globally distributed and at least half of the $\sim 30$ species are known to be toxic or to have other harmful effects (Anderson, 1997, 1998). On a morphological basis the Alexandrium genus has been divided into two subgenera: Alexandrium and Gessnerium (Balech, 1995). The placement of the first apical plate is distinctive, which in the Gessnerium is not connected to the apical pore

\footnotetext{
* Corresponding author.

E-mail address: hblossom@bio.ku.dk (H.E. Blossom).
}

complex (APC), as opposed to the Alexandrium. In addition, in Gessnerium the $1^{\prime}$ plate is under the $4^{\prime}$ plate rather than adjacent to it (Hasle et al., 1996). Species in the genus Alexandrium are well known for their production of paralytic shellfish poisoning (PSP) toxins, as well as spirolides, and gymnodimines (Cembella et al., 2000; Van Wagoner et al., 2011; Anderson et al., 2012). Additionally, a few members of the subgenus Gessnerium produce a toxin known as goniodomin A, namely A. hiranoi, A. pseudogonyaulax, and A. monilatum (Murakami et al., 1988; Hsia et al., 2006; Triki et al., 2016).

Species in the genus Alexandrium have historically been treated as phototrophic, using only light for energy and inorganic nutrients for growth. Recent studies have shown, however, that they are also able to consume other algae. At present, seven species of Alexandrium have been shown to exhibit phagotrophy: A. andersonii (Lee et al., 2016), A. catenella (Jeong et al., 2005a; Yoo et al., 2009), A. minutum (Jeong et al., 2005b), A. ostenfeldii 
(Jacobson and Anderson, 1996; Gribble et al., 2005), A. pohangense (Lim et al., 2015), A. pseudogonyaulax (Jacobson, 1999; Blossom et al., 2012), and A. tamarense (Jeong et al., 2005a; Yoo et al., 2009). Most of these reports have built their evidence for phagotrophy on the presence of food vacuoles in the cytoplasma of the Alexandrium cell and very little is known about prey capture and prey uptake.

Recently, direct evidence of prey capture and uptake has been shown through video recordings of two species: $A$. pohangense (Lim et al., 2015) and A. pseudogonyaulax (Blossom et al., 2012), in which both species engulf immobilized prey cells through the sulcus. While $A$. pohangense may use excreted lytic compounds to assist in prey capture through immobilization of prey cells (Lim et al., 2015), A. pseudogonyaulax, a member of the subgenus Gessnerium (Balech, 1995), possesses a prey capture technique involving the production of a mucus trap. This mucus trap is likely used in combination with excreted toxins, as supernatant of A. pseudogonyaulax has been shown to lyse other protist cells (Blossom et al., 2012). Potential motile prey cells which swim into the mucus trap are caught, immobilized, and then can be consumed by the A. pseudogonyaulax cell (Blossom et al., 2012). The only other dinoflagellates known to produce mucus for prey capture are the heterotrophic Noctiluca scintillans (Kirchner et al., 1996) and Dinophysis spp. (Mafra et al., 2016; Ojamäe et al., 2016; Papiol et al., 2016). N. scintillans can only slowly move and mainly floats in the water column catching prey in the mucus, which is attached to the tip of its tentacle. When the mucus trap is full of prey and detritus, the cell will feed upon the whole trap (Kiørboe and Titelman, 1998). Dinophysis acuta (Ojamäe et al., 2016; Papiol et al., 2016), D. acuminata (Ojamäe et al., 2016), and D. cf. ovum (Mafra et al., 2016) have now also been shown to produce mucus used for prey capture, and although slightly different, prey get trapped in a similar way that has been seen for A. pseudogonyaulax.

Thus far, knowledge of the mucus trap in Alexandrium is limited, and it has only been documented in the Alexandrium species A. pseudogonyaulax (Blossom et al., 2012). The goal of this study was to first complete a broad screening of Alexandrium species to determine how widespread phagotrophy and mucus trap formation is in this genus, particularly in the species of the subgenus Gessnerium; and second, determine the frequency and rate of trap formation in A. pseudogonyaulax as well as the fate of both the trap, and the cells caught within the trap after the trap has been discarded by A. pseudogonyaulax. This information could help to assess the potential impact of this strategy on co-occurring protists.

\section{Methods}

\subsection{Strains and culture conditions}

Cultures used in this study included five strains of Alexandrium pseudogonyaulax, three strains of $A$. tamarense and one strain of A. ostenfeldii, A. catenella, A. taylorii, A. margalefii, A. hiranoi and A. insuetum (Table 1). Algal cultures were obtained from the Scandinavian Culture Collection for Algae and Protozoa (SCCAP), the Cawthron Institute Culture Collection for Micro-Algae and Protozoa (CAWD), the Marine Biological Section of the University of Copenhagen in Helsingør, Denmark (MBL), and the National Center for Marine Algae and Microbiota (formerly the CCMP). The A. taylorii strain was provided by Antonella Penna. The organisms used as potential prey were the cryptophytes Teleaulax acuta, Rhodomonas salina, and Hemiselmis sp., the ciliate Mesodinium rubrum and the dinoflagellate Heterocapsa rotundata (Table 1). All cultures, including prey organisms, were maintained in $f / 2$ medium with salinity of 30 , and kept at $15^{\circ} \mathrm{C}$ with an irradiance of $90-120 \mu \mathrm{mol}$ photons $\mathrm{m}^{-2} \mathrm{~s}^{-1}$ using cool white light on a 14:10 h light:dark cycle.
Table 1

Cultures used in the experiments with species name, strain number, isolation place and date. The K-strains were provided from SCCAP. See Table 3 for strain names of $A$. tamarense and $A$. ostenfeldii isolated from western Greenland.

\begin{tabular}{llll}
\hline Species & Strain & Isolation place & Date \\
\hline A. pseudogonyaulax & CAWD54 & Tamaki Strait, New Zealand & 1997 \\
A. pseudogonyaulax & CAWD138 & Kerikeri, New Zealand & 2004 \\
A. pseudogonyaulax & MBL-AP2 & Helsingør, Denmark & 2010 \\
A. pseudogonyaulax & MBL-AP1 & Helsingør, Denmark & 2010 \\
A. pseudogonyaulax & K-1344 & Limfjorden, Denmark & 2009 \\
A. pseudogonyaulax & K-1345 & Limfjorden, Denmark & 2009 \\
A. hiranoi & CCMP-2215 & Misaki, Japan & 1984 \\
A. taylorii & CBA-4 & Aeolian Is., Italy & 2009 \\
A. margalefii & CAWD10 & Bream Bay, New Zealand & 1993 \\
A. insuetum & CCMP-2082 & Uchiumi Bay, Japan & 1985 \\
A. tamarense & H7 & Argentina & 2012 \\
A. tamarense & H5 & Argentina & 2012 \\
A. tamarense & Alex 2 & Scotland & 2009 \\
A. ostenfeldii & K-1354 & Helsingør, Denmark & 2009 \\
A. catenella & K-1490 & Canada & 2010 \\
A. ostenfeldii & 19 strains & West Greenland & 2012 \\
A. tamarense & 15 strains & West Greenland & 2012 \\
Heterocapsa rotundata & K-0483 & Denmark & 1988 \\
Teleaulax acuta & K-1486 & Nivå bay, Denmark & 2009 \\
Mesodinium rubrum & MBL- & Helsingør, Denmark & 2009 \\
Rhodomonas salina & DK2009 & & \\
Kemiselmis sp. & K-0513 & France & unknown \\
\hline
\end{tabular}

In addition, 15 strains of $A$. tamarense and 19 strains of A. ostenfeldii from western Greenland isolated approximately 4 months prior to the feeding experiments (Tillmann et al., 2014, 2016) were used. These strains were maintained as stated above, except that they were kept at $10^{\circ} \mathrm{C}$ with $20 \mu \mathrm{mol}$ photons $\mathrm{m}^{-2} \mathrm{~s}^{-1}$. Cultures used as prey organisms for the Greenlandic strains were acclimated to $10^{\circ} \mathrm{C}$ for at least one week prior to experiments. All experiments were done in the same conditions that the Alexandrium cultures were maintained at.

\subsection{Experiment 1. Screening for food uptake, mucus production, and trap formation in Alexandrium spp.}

A broad screening for food uptake in species belonging to the genus Alexandrium was performed using 5 species from the subgenus Gessnerium: A. hiranoi (CCMP-2215), A. insuetum (CCMP2082), A. margalefii (CAWD10), A. pseudogonyaulax (five strains: K-1344, K-1345, MBL-AP1, CAWD138, and CAWD54), and A. taylorii (CBA-4), as well as 3 species from the Alexandrium subgenus: A. catenella (K-1490), A. ostenfeldii (four strains: K-1354, as well as P1F6, P1G11 and P2F4 from Greenland), and A. tamarense (six strains: H5, H7, Alex 2, including P2G7, P2G12 and P2H7 from Greenland). A rough screening of the remaining Greenlandic strains was also done with different concentrations as stated below. The cryptophyte, Teleaulax acuta, was chosen as a potential prey species mainly because it co-occurs with Alexandrium spp. in nature and is a known prey of $A$. pseudogonyaulax (Blossom et al., 2012), but also because of its orange autofluorescence, which contrasts with the red autofluorescence of Alexandrium spp., making it clearly visible as a food vacuole when consumed.

Exponentially growing Alexandrium cultures were mixed with $T$. acuta in a ratio of $1: 5$ or $1: 10$, in concentrations of 100:500, $300: 1500$ and $300: 3000$ cells ml $\mathrm{m}^{-1}$, depending on the original concentration of the culture. These were placed in triplicate wells of a 24 -well plate with $\mathrm{f} / 2$ medium for a total volume of $2.5 \mathrm{ml}$. The remaining Greenlandic strains were tested by adding $1 \mathrm{ml}$ of a dense culture ranging from approximately 500 to 1000 cells ml ${ }^{-1}$ and $1 \mathrm{ml}$ of a dense culture of $T$. acuta, ranging from 1 to $6 \times 10^{4}$ cells ml $\mathrm{m}^{-1}$ to triplicate wells on a 24 -well plate. Triplicate control wells with only the Alexandrium species in $f / 2$ medium 
were also set up. Another control in the form of a well with $A$. pseudogonyaulax which was known to feed regularly (strain $\mathrm{K}-1344$, or CAWD138 acclimated to $10^{\circ} \mathrm{C}$ for the Greenlandic strains) mixed with $T$. acuta was also made in all screenings performed to make sure that the fixation worked and that food vacuoles would be visible in the Alexandrium; the A. pseudogonyaulax cells that had engulfed $T$. acuta cells could thereby be used as a positive control. After $24 \mathrm{~h}$ at culture conditions, all wells were observed under the light microscope to assess if any of the Alexandrium species had produced mucus or formed a mucus trap. This was done by looking for clumping or struggling behavior of the prey species as well as dragging behavior by the Alexandrium cell. After these observations, all samples were fixed with glutaraldehyde to a final concentration of $2 \%(\mathrm{v} / \mathrm{v})$, collected onto black polycarbonate filters ( $5 \mu \mathrm{m}$ pore size). All samples were examined under a light microscope (BX50, Olympus, Japan) with epifluorescence using a U-MWG wide band green fluorescence filter cube with excitation wavelength of 510-550 nm (Olympus, Japan). At least 200 cells in each triplicate were checked for the presence of food vacuoles.

To examine if additional time was needed to induce feeding or if other prey species were preferred, additional incubation time and prey species were offered to a subset of the Alexandrium strains used above (Table 2).

\subsection{Observations from the field: formation of mucus in A. pseudogonyaulax collected from field samples}

In order to confirm that the mucus traps of $A$. pseudogonyaulax are formed and used in the nature, microscopic observations were made of $A$. pseudogonyaulax cells obtained from fresh plankton tows and water samples directly from Helsingør harbor, Denmark using an inverted microscope (CK2, Olympus, Japan). These were kept in tissue culture flasks under culture conditions and observed immediately and after $24 \mathrm{~h}$. At least $20 \mathrm{~A}$. pseudogonyaulax cells with mucus traps were observed and the organisms that had been caught were identified. Photographs of food vacuoles in $A$. pseudogonyaulax were taken using a microscope (BX50, Olympus, Japan) equipped with a camera (DP71, Olympus, Japan) with both normal light and epifluorescence.

\subsection{Experiment 2. Prey specificity and prey uptake in A. pseudogonyaulax}

To test prey specificity in A. pseudogonyaulax (K-1344), different prey species were offered in a screening experiment. Prey species consisted of $A$. hiranoi (CCMP-2215), Hemiselmis sp. (K-0513), Heterocapsa rotundata (K-0483), Mesodinium rubrum '(MBLDK2009), and Rhodomonas salina (K-1487). The screening was

Table 2

Species used for additional feeding experiments and the incubation time after addition of prey species. $\mathrm{Ta}=T$. acuta, $\mathrm{He}=$ Hemiselmis sp., Rs $=$ Rhodomonas salina, $\mathrm{Mr}=$ Mesodinium rubrum.

\begin{tabular}{lll}
\hline Alexandrium spp. & Prey offered & Incubation time $(\mathrm{h})$ \\
\hline A. taylorii (CBA-4) & $\mathrm{Ta}$ & 48,72 \\
A. catenella $(\mathrm{K}-1490)$ & $\mathrm{Ta}$ & 24 \\
A. tamarense (Alex 2) & $\mathrm{Ta}$ & 24 \\
A. tamarense (P2G7) & $\mathrm{He}$ & 24 \\
A. tamarense (P2H7) & $\mathrm{He}$ & 24 \\
A. tamarense (P2G12) & $\mathrm{He}$ & 24 \\
A. ostenfeldii (P2F4) & $\mathrm{He}$ & 24 \\
A. ostenfeldii (P1G11) & $\mathrm{He}$ & 24 \\
A. ostenfeldii (P1F6) & $\mathrm{He}$ & 24 \\
A. tamarense (H5) & $\mathrm{He}, \mathrm{Rs}, \mathrm{Mr}$ & 48 \\
A. ostenfeldii (K-1354) & $\mathrm{He}, \mathrm{Rs}, \mathrm{Mr}$ & 48 \\
A. taylorii (CBA-4) & $\mathrm{He}, \mathrm{Rs}, \mathrm{Mr}$ & 48 \\
\hline
\end{tabular}

performed with a predator:prey ratio of $1: 5$ and a concentration of 100:500 cells $\mathrm{ml}^{-1}$. The exponentially growing $A$. pseudogonyaulax culture and the different prey species were mixed in triplicates in a 24-well plate. Additionally, a control well was made with A. pseudogonyaulax cells alone. After $24 \mathrm{~h}$ at culture conditions, observations of living cells were made to see if traps were formed and prey species were caught. To confirm feeding by A. pseudogonyaulax on the specific prey species which have orange autofluorescence (Hemiselmis sp., M. rubrum, and $R$. salina), samples were fixed in a final concentration of $2 \%$ glutaraldehyde $(\mathrm{v} / \mathrm{v})$ and collected on black polycarbonate filters as described above. All or at least $200 \mathrm{~A}$. pseudogonyaulax cells were examined for each triplicate. The cells in the treatments with $H$. rotundata and A. hiranoi were not mounted on a black filter, but instead the examination for food vacuoles in A. pseudogonyaulax was done directly in the well using an inverted light microscope (CK2, Olympus, Japan). In this case, food vacuoles, when present, were visible but were not as obvious as when using prey species with contrasting autofluorescence, and thus this method was not as efficient as the method described above using epifluorescence.

\subsection{Experiment 3. Quantitative analyses of mucus trap formation in} A. pseudogonyaulax

To track the frequency and rate of mucus trap formation in individual A. pseudogonyaulax cells when mixed with prey, single cells were isolated, mixed with $H$. rotundata, and observed after 1 , 2, 3, 4 and $24 \mathrm{~h}$ and in one case, after 48 and $72 \mathrm{~h}$. For single cell isolation, a $1 \mathrm{ml}$ sample from an exponentially growing culture of A. pseudogonyaulax (strains K-1344 and CAWD138) was taken and transferred to a clean Sedgewick-Rafter chamber. Cells were then isolated using glass micropipette and transferred to a well containing $200 \mu \mathrm{l} \mathrm{f} / 2$ medium in a 96-well plate. This was left for about an hour at culture conditions so the recently isolated cells could acclimate. A culture of $H$. rotundata with a known cell concentration was diluted to a concentration of $5 \times 10^{3}$ and $1 \times 10^{5}$ cells ml $\mathrm{ml}^{-1}$ and $100 \mu \mathrm{l}$ of this solution was added to the wells containing individual $A$. pseudogonyaulax cells to a final prey number of either 500 ("low") or $1 \times 10^{4}$ ("high") cells per well. The ratio of $A$. pseudogonyaulax to prey was thereby $1: 500$ and $1: 10,000$. The number of individual $A$. pseudogonyaulax observed was between 17 and 44 cells (strain K-1344 with 500 prey $n=29$ and with 10,000 prey $n=44$; strain CAWD138 with 500 prey $n=25$ and with 10,000 prey $n=17$ ).

The plate containing the $A$. pseudogonyaulax cells was incubated at $15^{\circ} \mathrm{C}$ on a light table under the standard culture conditions. Observations of each well were done after 1, 2, 3, 4 and $24 \mathrm{~h}$, by scanning the entire well under an inverted light microscope and recording the number of traps, the number of prey caught in each trap, the maximum length of each trap (longest axis), and whether or not the Alexandrium cell was attached to the trap. For strain $\mathrm{K}-1344$, incubation was continued and observations were made at 48 and $72 \mathrm{~h}$. Traps were identified as a group of $H$. rotundata cells clumped together, with a minimum of three prey cells constituting a trap. An example of a mucus trap with $H$. rotundata caught in it is shown in Fig. 1. With experience, these traps are quite easily recognized, however it is only the prey that is visible. For this reason, a relatively high concentration of $H$. rotundata was chosen as prey as they are less likely to lyse, and thus would be visible over time.

Since it is the entrapped prey that makes a trap recognizable, it is impossible to visualize traps without prey present. Despite this, it was important to attempt to determine if traps are formed at all times, even in monoculture, or if they are formed only in response to the presence of prey. The A. pseudogonyaulax cells' swimming behavior when attached to a trap is quite distinct. The trap is 


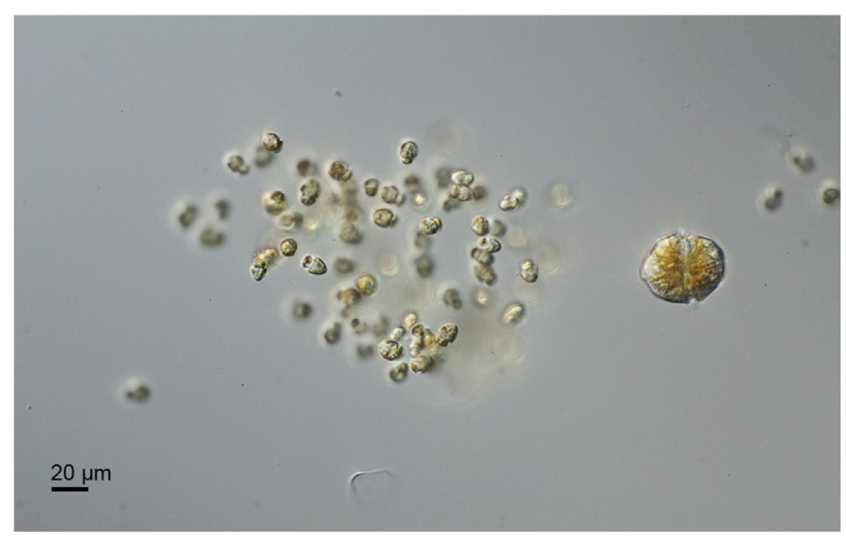

Fig. 1. The mucus trap of $A$. pseudogonyaulax. An A. pseudogonyaulax cell is dragging behind a mucus trap which has caught many $H$. rotundata cells. usually stationary and at the bottom, and the A. pseudogonyaulax cell swims back upon itself in a dragging motion, and cannot swim forward quickly, if at all. Therefore, swimming behavior was observed in single cells placed in wells of a 96 well plate without prey and compared to the swimming behavior of cells with prey and thus visible traps.

\subsection{Experiment 4. Fate of the prey cells caught in an abandoned mucus trap}

This experiment was performed to determine what happens to the prey cells trapped in an abandoned mucus trap, when no freeswimming $H$. rotundata cells remained in the medium. This was done in order to examine to what extent the prey cells could escape from the mucus trap, without influence from the $A$. pseudogonyaulax cell. An exponentially growing culture of $A$. pseudogonyaulax (strain CAWD138) with a known cell number was diluted with $\mathrm{f} / 2$ medium and mixed with a culture of $H$. rotundata to a final ratio of 1:100 in a $65 \mathrm{ml}$ tissue culture flask and incubated at

Table 3

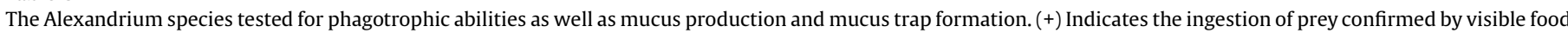

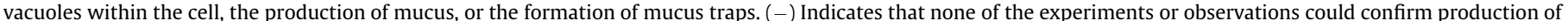
mucus or the ingestion of prey. The Greenlandic strains are indicated with $(\dagger)$ and those that were tested with more than one type of prey indicated with $(*)$.

\begin{tabular}{|c|c|c|c|}
\hline Species/strain & Food vacuoles & Formation of traps & Mucus production \\
\hline A. catenella $\mathrm{K}-1490$ & - & - & - \\
\hline A. hiranoi CCMP-2215 & - & - & - \\
\hline A. insuetum CCMP-2082 & - & - & - \\
\hline A. margalefii CAWD10 & - & - & - \\
\hline A. ostenfeldii $\mathrm{K}-1354$ & - & - & - \\
\hline A. ostenfeldii P1D5 $\dagger$ & - & - & - \\
\hline A. ostenfeldii $\mathrm{P} 1 \mathrm{~F} 4 \dagger$ & - & - & - \\
\hline A. ostenfeldii P1F5 $\dagger$ & - & - & - \\
\hline A. ostenfeldii P1F6+* & - & - & - \\
\hline A. ostenfeldii P1F8 $†$ & - & - & - \\
\hline A. ostenfeldii $\mathrm{P} 1 \mathrm{~F} 11 \dagger$ & - & - & - \\
\hline A. ostenfeldii P1G3† & - & - & - \\
\hline A. ostenfeldii $\mathrm{P} 1 \mathrm{G} 5 \dagger$ & - & - & - \\
\hline A. ostenfeldii $\mathrm{P} 1 \mathrm{G} 11 \dagger^{*}$ & - & - & - \\
\hline A. ostenfeldii $\mathrm{P} 1 \mathrm{H} 10 \dagger$ & - & - & - \\
\hline A. ostenfeldii $\mathrm{P} 2 \mathrm{~F} 3 \dagger$ & - & - & - \\
\hline A. ostenfeldii $\mathrm{P} 2 \mathrm{~F} 4 \dagger^{*}$ & - & - & - \\
\hline A. ostenfeldii $\mathrm{P} 2 \mathrm{G} 9 \dagger$ & - & - & - \\
\hline A. ostenfeldii $\mathrm{P} 2 \mathrm{H} 2 \dagger$ & - & - & - \\
\hline A. ostenfeldii $\mathrm{P} 2 \mathrm{H} 4 \dagger$ & - & - & - \\
\hline A. ostenfeldii $\mathrm{P} 2 \mathrm{H} 8 \dagger$ & - & - & - \\
\hline A. ostenfeldii $\mathrm{P} 3 \mathrm{~F} 1 \dagger$ & - & - & - \\
\hline A. ostenfeldii $\mathrm{P} 4 \mathrm{E} 3 \dagger$ & - & - & - \\
\hline A. ostenfeldii $\mathrm{P} 4 \mathrm{~F} 4 \dagger$ & - & - & - \\
\hline A. pseudogonyaulax $\mathrm{K}-1344$ & + & + & + \\
\hline A. pseudogonyaulax K-1345 & + & + & + \\
\hline A. pseudogonyaulax MBL-AP1 & + & + & + \\
\hline A. pseudogonyaulax CAWD138 & + & + & + \\
\hline A. pseudogonyaulax CAWD54 & - & + & + \\
\hline A. tamarense Alex 2 & - & - & - \\
\hline A. tamarense $\mathrm{H} 5$ & - & - & - \\
\hline A. tamarense $\mathrm{H} 7$ & - & - & - \\
\hline A. tamarense $\mathrm{P} 1 \mathrm{H} 8 \dagger$ & - & - & - \\
\hline A. tamarense $\mathrm{P} 1 \mathrm{H} 4 \dagger$ & - & - & - \\
\hline A. tamarense $\mathrm{P} 2 \mathrm{E} 5 \dagger$ & - & - & - \\
\hline A. tamarense $\mathrm{P} 2 \mathrm{E} 6 \dagger$ & - & - & - \\
\hline A. tamarense $\mathrm{P} 2 \mathrm{G} 7 \dagger^{*}$ & - & - & - \\
\hline A. tamarense $\mathrm{P} 2 \mathrm{G} 12 \dagger^{*}$ & - & - & - \\
\hline A. tamarense $\mathrm{P} 2 \mathrm{H} 7 \dagger^{*}$ & - & - & - \\
\hline A. tamarense $\mathrm{P} 2 \mathrm{G} 5 \dagger$ & - & - & - \\
\hline A. tamarense $\mathrm{P} 2 \mathrm{G} 6 \dagger$ & - & - & - \\
\hline A. tamarense $\mathrm{P} 2 \mathrm{H} 6 \dagger$ & - & - & - \\
\hline A. tamarense $\mathrm{P} 2 \mathrm{H} 10 \dagger$ & - & - & - \\
\hline A. tamarense $\mathrm{P} 3 \mathrm{~B} 10 \dagger$ & - & - & - \\
\hline A. tamarense $\mathrm{P} 3 \mathrm{C} 1 \dagger$ & - & - & - \\
\hline A. tamarense $\mathrm{P} 3 \mathrm{H} 6 \dagger$ & - & - & - \\
\hline A. tamarense $\mathrm{P} 3 \mathrm{H} 8 \dagger$ & - & - & - \\
\hline A. taylorii $\mathrm{CBA}-4$ & - & - & + \\
\hline
\end{tabular}


culture conditions for $24 \mathrm{~h}$. After $24 \mathrm{~h}$, several mucus traps were present containing $H$. rotundata cells. A $1 \mathrm{ml}$ sample of this solution was transferred to a clean Sedgewick-Rafter chamber where 30 traps, without the A. pseudogonyaulax cell were isolated by micropipette. Each trap was carefully washed in two drops of $f /$ 2 medium to avoid transferring any free-swimming $H$. rotundata, and then placed in a well, on a 96-well plate, each containing $250 \mu \mathrm{lf} / 2$ medium. The trapped $H$. rotundata cells were counted initially and the 96 -well plate was placed at culture conditions. The number of prey in each individual trap was counted every $12 \mathrm{~h}$ for $48 \mathrm{~h}$ using an inverted light microscope. If there was a visibly lysed $H$. rotundata cell, this was counted as a lysed cell.

\subsection{Experiment 5. Ability of the abandoned mucus traps to catch prey}

This experiment was done to determine the fate of the mucus trap after being abandoned by the A. pseudogonyaulax cell and to see if the mucus continued to catch prey regardless of the attachment of the A. pseudogonyaulax cell. Here, the number of prey cells in the trap was counted, when left with a known concentration of prey cells in the medium, after the A. pseudogonyaulax cell was removed; this includes new cells getting trapped as well as those remaining captured in a trap.

An exponentially growing culture of $A$. pseudogonyaulax (CAWD138) with a known cell density was diluted with $f / 2$ medium to a final concentration of 4 cells $\mathrm{ml}^{-1}$ of which $200 \mu \mathrm{l}$ was added to one well on a 96-well plate. Only the wells with exactly one A. pseudogonyaulax cell, which had also formed a trap was used as replicate wells ( 33 wells). In addition, a culture of $H$. rotundata with a known cell density was diluted to a concentration of 1000 cells $\mathrm{ml}^{-1}$ and $100 \mu \mathrm{l}$ of this solution was added in each well with the Alexandrium cells giving a total number of 100 prey cells in each well.

The plates were incubated for $24 \mathrm{~h}$ at culture conditions to allow the $A$. pseudogonyaulax to form mucus traps. After the incubation, 33 wells, all containing mucus traps, were selected as replicates and the A. pseudogonyaulax cells were removed by single-cell isolation, leaving behind the mucus traps with captured prey cells as well as free-swimming prey cells. The locations of the mucus traps on the bottom of each well were recorded, as well as the number of prey in each trap. The whole well was threedimensionally scanned for the presence of traps, but nearly all traps were located at the bottom of the well. The number of prey cells in each individual trap was then counted every $12 \mathrm{~h}$ for $48 \mathrm{~h}$ using an inverted light microscope.

\section{Results}

\subsection{Experiment 1. Screening for food uptake in Alexandrium spp.}

Among the Alexandrium species tested for phagotrophy only A. pseudogonyaulax was confirmed to ingest food. The A. pseudogonyaulax strains K-1344, K-1345, CAWD138, MBL-AP1 all had visible food vacuoles of the cryptophyte Teleaulax acuta when mixed for $24 \mathrm{~h}$ (Table 3 ). One strain of A. pseudogonyaulax (CAWD54) and all other species of the genus Alexandrium tested were not confirmed to take up food particles (Table 3). None of the selected Alexandrium species offered additional prey species or allowed more time to interact with the prey species (Table 2), were found with food vacuoles.

Orange accumulation bodies $(\mathrm{OAB})$ were found in monoculture of many of the strains from Greenland, as well as in $A$. pseudogonyaulax CAWD138 acclimated to $10^{\circ} \mathrm{C}$. These OAB might resemble food vacuoles as they were similar in size to a $T$. acuta cell, but were distinguished from food vacuoles based on the brightness and number of vacuoles; there was always only one OAB per cell, and this was dim orange compared to the bright orange $T$. acuta cells surrounding the Alexandrium cell on the black filter or, in the case of $A$. pseudogonyaulax, fluorescing from inside food vacuoles.

\subsection{Observations of mucus production and trap formation in Alexandrium spp.}

Only A. pseudogonyaulax and A. taylorii were found to produce mucus. Three strains of $A$. pseudogonyaulax (CAWD138, K-1344, and $\mathrm{K}-1345)$ produced typical mucus traps, similar to what has been observed before (Blossom et al., 2012). The last $A$. pseudogonyaulax strain CAWD54 was only observed with very few mucus traps and some mucus threads when mixed with prey compared to all other strains of $A$. pseudogonyaulax; this strain was
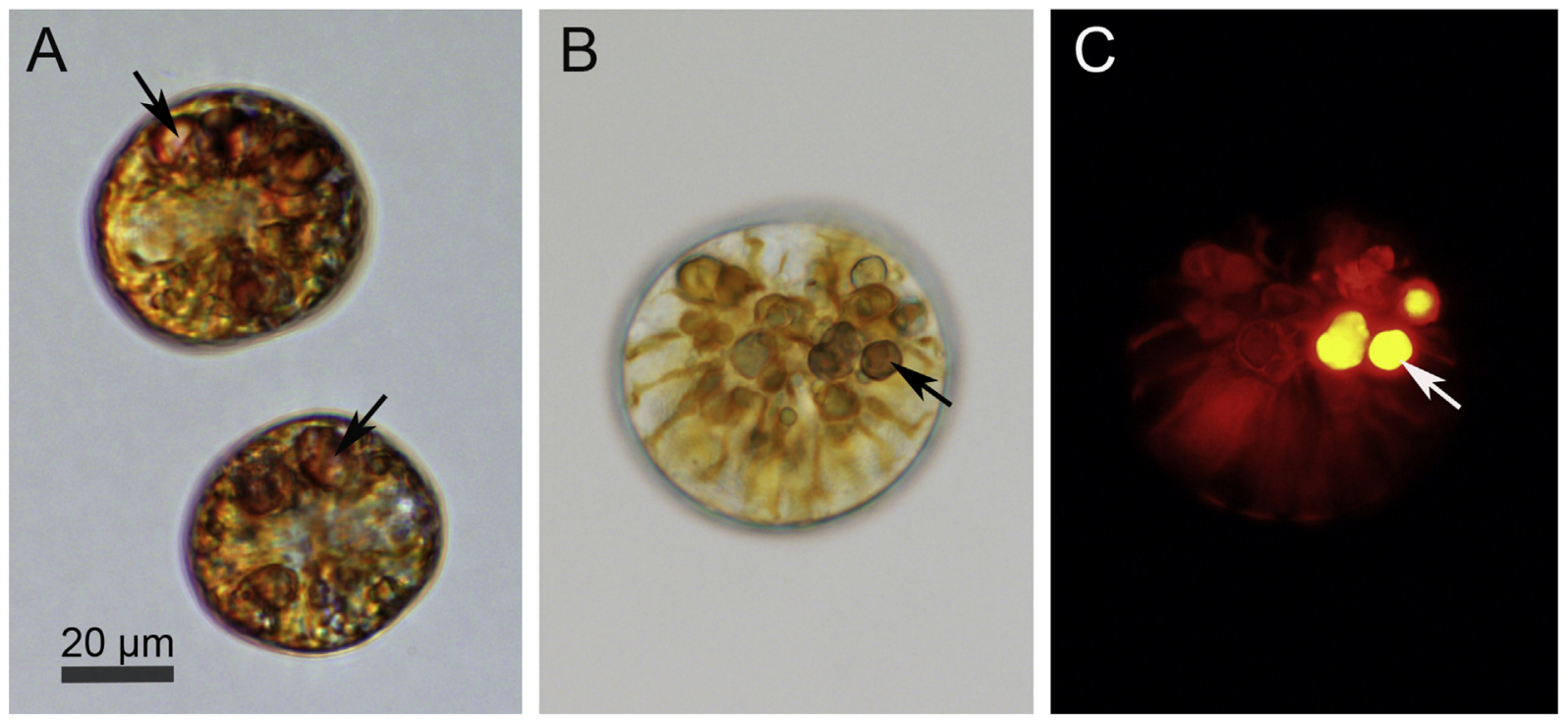

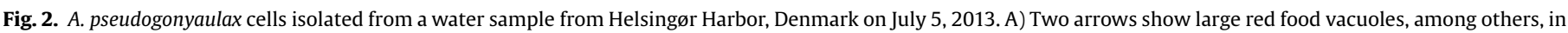

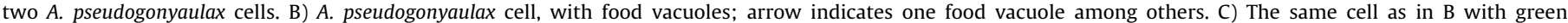

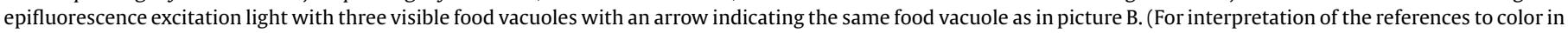
this figure legend, the reader is referred to the web version of this article.) 
also the only $A$. pseudogonyaulax strain in which food vacuoles were not observed (Table 3 ). Mucus formation in A. taylorii cultures was visible, regardless of the presence of prey. The cells formed large shared formations of mucus threads with the cells attached. Each cell formed a distinct mucus thread extruding from the sulcal groove that attached to surfaces and other threads produced by other cells. The cells circled the attachment point and seemed to form a thicker formation. After a few days, thick threads of mucus extended from the bottom of the $65 \mathrm{ml}$ tissue culture flask to the surface (several centimeters long). The cells of $A$. taylorii surrounded the mucus threads, moving sporadically but still attached to the mucus. When $A$. taylorii was mixed with prey species such as $T$. acuta or $H$. rotundata, the prey only got stuck in the mucus to a minor degree and seemed to be able to escape again most of the time.

\subsection{Observations from the field: formation of mucus traps in A.} pseudogonyaulax cells collected from field samples

Microscopic examinations of fresh plankton tow samples, which were observed within $24 \mathrm{~h}$, provided evidence of the production of mucus traps by A. pseudogonyaulax in situ as well as the capture of other protists such as diatoms, Protoperidinium species and small heterotrophic flagellates. Food vacuoles were visible in freshly collected $A$. pseudogonyaulax confirming the ingestion of prey in situ (Fig. 2 and Table 4). These food vacuoles ranged in size, color, and autofluorescence, but a taxonomic determination of the ingested prey was not possible.

\subsection{Experiment 2. Prey specificity in A. pseudogonyaulax}

Different prey items were offered to A. pseudogonyaulax to examine the range of prey types that $A$. pseudogonyaulax is able to feed upon. Hemiselmis sp., Heterocapsa rotundata, Mesodinium rubrum, Rhodomonas salina, and Teleaulax acuta were shown to be acceptable prey items for $A$. pseudogonyaulax and were all engulfed and visible as food vacuoles in a light microscope or illuminated by epifluorescence (Table 4). In order to see if A. pseudogonyaulax would feed on a bigger, closely related species, A. hiranoi was offered as prey, also to see if it could resist getting caught in the mucus traps. After $24 \mathrm{~h} A$. hiranoi was not caught in the mucus traps formed by $A$. pseudogonyaulax and was not eaten (Table 4).

\subsection{Experiment 3. Quantitative analysis of mucus trap formation in A. pseudogonyaulax}

The percentage of $A$. pseudogonyaulax cells forming mucus traps varied slightly between strains, but mainly depended on prey concentration. When prey cells were abundant $\left(1 \times 10^{4}\right.$ cells ml $\left.^{-1}\right)$,

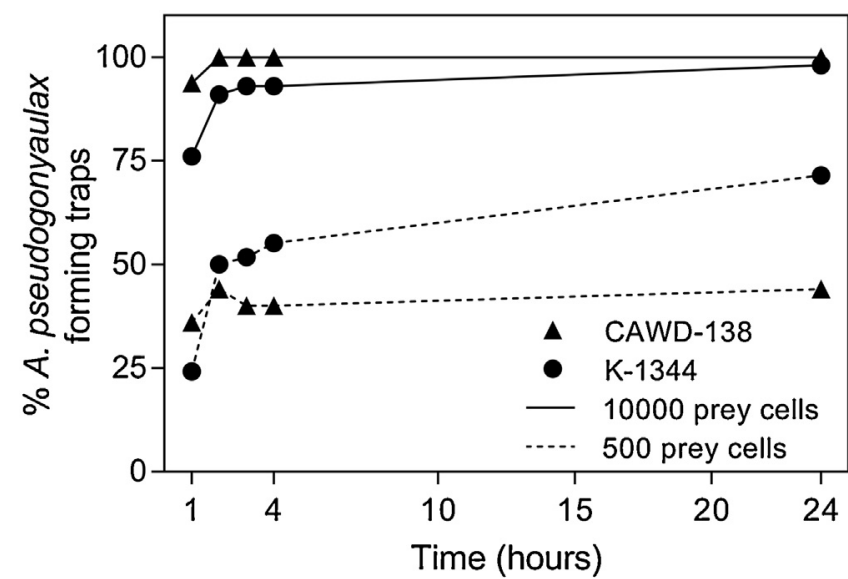

Fig. 3. Fraction of A. pseudogonyaulax cells forming at least one trap. Triangles represent strain CAWD138, and circles represent strain K-1344. Solid lines represent high prey concentration of $1 \times 10^{4} \mathrm{H}$. rotundata cells per well and dashed lines represent the lower prey concentration of 500 H.rotundata cells per well.

nearly $100 \%$ of all individual cells of both strains were capable of forming traps, and they did so within $24 \mathrm{~h}$ after exposure to prey, with $100 \%$ of one strain forming traps after just $2 \mathrm{~h}$ (Fig. 3 ). At low prey concentrations, some A. pseudogonyaulax cells did not form visible traps: after $24 \mathrm{~h}, 44 \%$ of strain CAWD138 and $71 \%$ of strain K1344 had formed a trap (Fig. 3). Many of the cells formed traps within minutes (personal observations) and by $1 \mathrm{~h}$ with high prey concentration, $76 \%$ of strain CAWD138 and $94 \%$ of $\mathrm{K}-1344$ had formed a trap (Fig. 3).

The average number of traps produced by each $A$. pseudogonyaulax cell increased over time (Fig. $4 \mathrm{~A}$ and B). After $72 \mathrm{~h}$ the average number of traps per $A$. pseudogonyaulax cell was 5 , but, the maximum number of traps produced by one cell was 11 (Fig. 5). After just $1 \mathrm{~h}, 67 \%$ of the A. pseudogonyaulax cells had formed one trap, and $7 \%$ of the cells had already made two traps (Fig. 5). At $24 \mathrm{~h}$, most $A$. pseudogonyaulax cells had formed at least three traps (Fig. 5). The total number of prey caught by each individual $A$. pseudogonyaulax cell increased over time, and was higher at elevated prey concentrations (Fig. 4C and D).

The slight increase over time in total prey caught reflects an increase in the number of traps, rather than an increase in prey per trap, as the average number of prey per trap increased initially and then started to decrease after $2-5 \mathrm{~h}$, with the exact time varying with prey concentration and strain (Fig. 4E and F). Overall, when the prey concentration was high, there were more prey cells caught per trap than when the prey concentration was low (Fig. 4E and F). In the first $4 \mathrm{~h}$, at each time point, most of the traps had between 31 and 60 prey cells in each, but the range was large, with some traps

Table 4

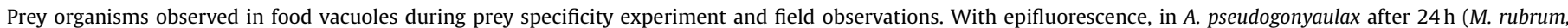

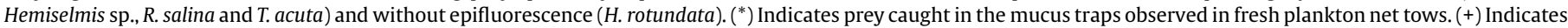

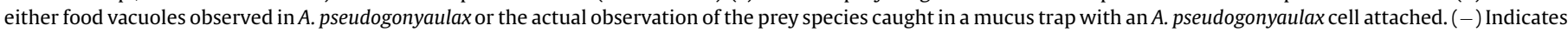

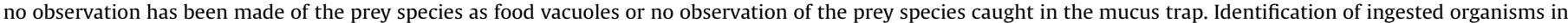
plankton tow samples was not possible ("unknown").

\begin{tabular}{|c|c|c|}
\hline Prey organism & Visible as food vacuoles & Caught in mucus trap \\
\hline M. rubrum & + & + \\
\hline H. rotundata & + & + \\
\hline Hemilselmis sp. & + & + \\
\hline R. salina & + & + \\
\hline T. acuta & + & + \\
\hline A. hiranoi & - & - \\
\hline *Protoperidinium spp. & Unknown & + \\
\hline *Diatoms & Unknown & + \\
\hline *Small heterotrophic flagellates & Unknown & + \\
\hline
\end{tabular}


CAWD-138
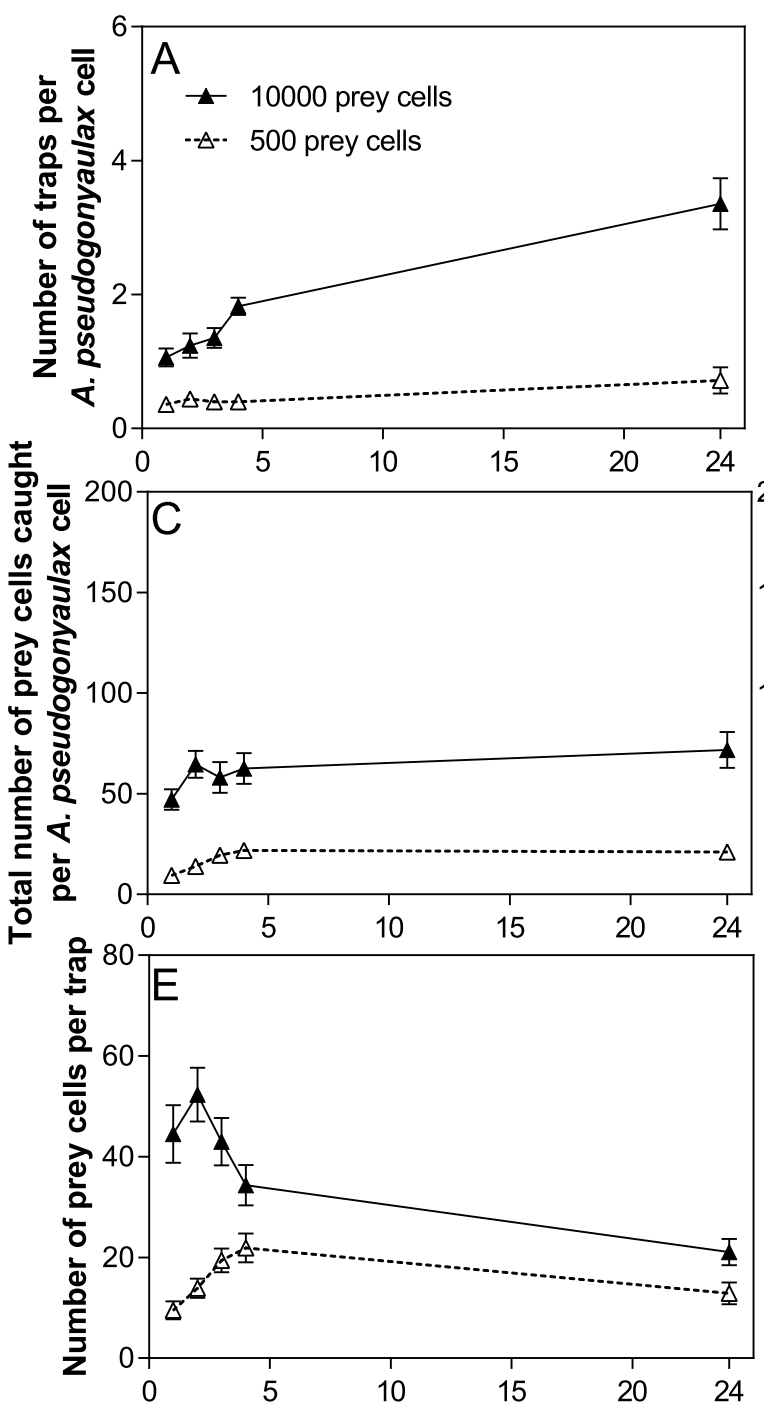

$\mathrm{K}-1344$
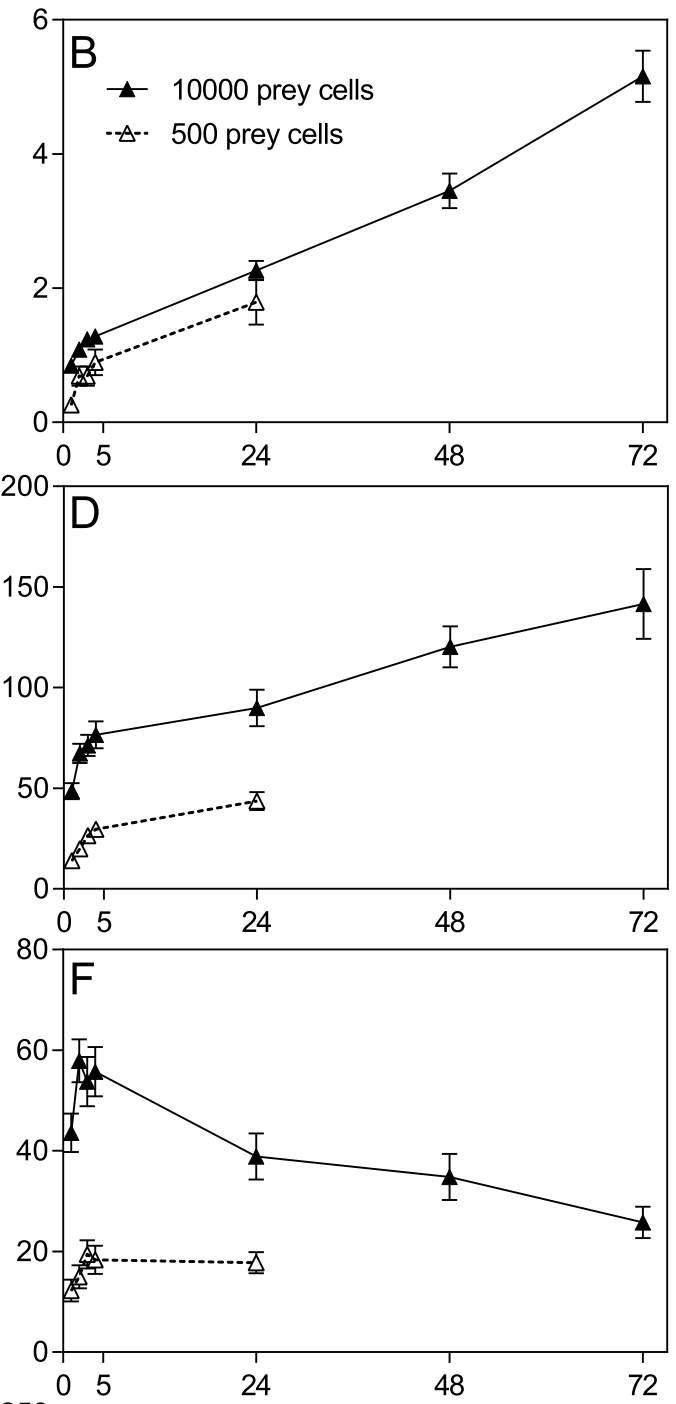
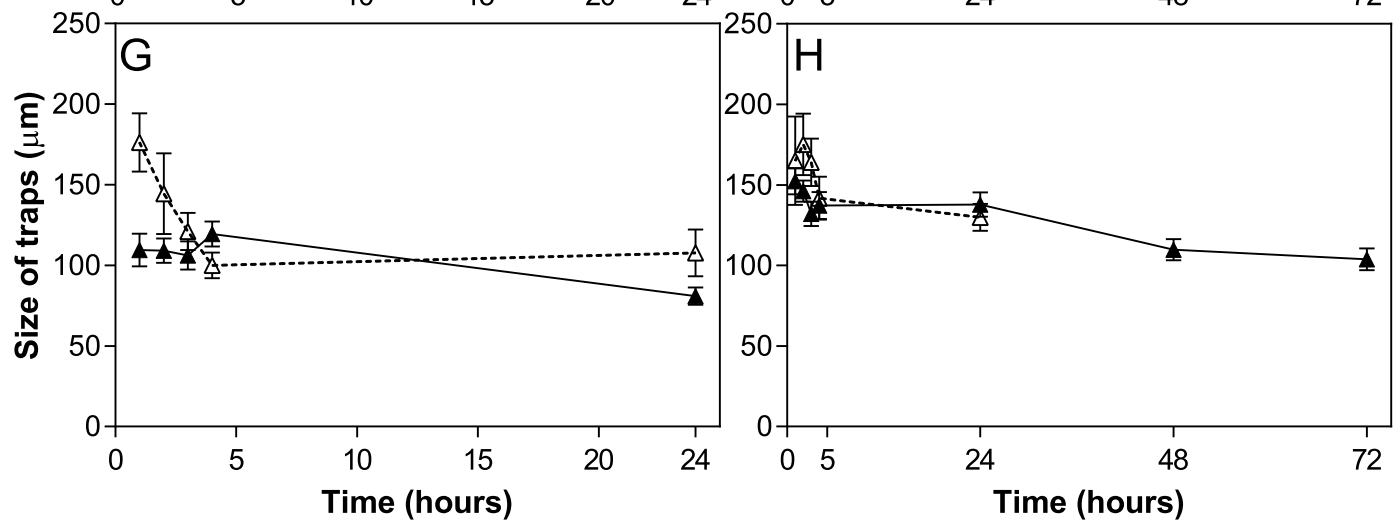

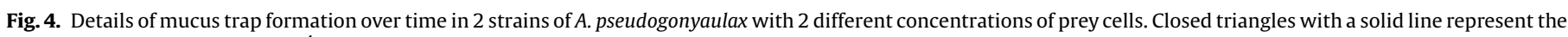

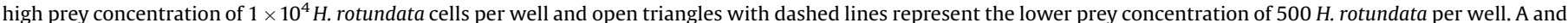

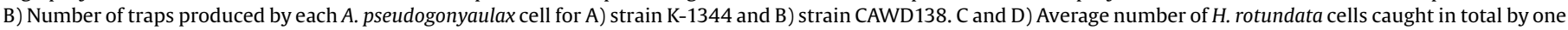

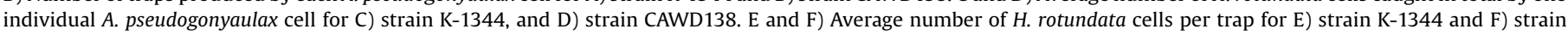

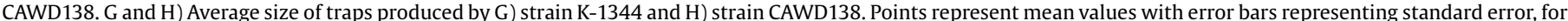

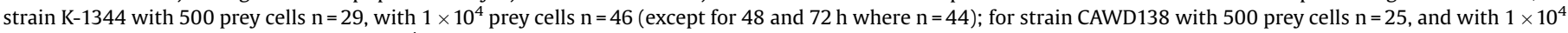

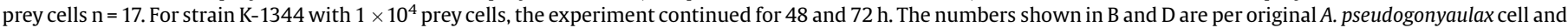
does account for cell division.

containing 3 cells and some containing 128 prey cells (Fig. 6). Towards the end of the experiment when there were many abandoned traps, most of the traps contained between 3 and 30 prey cells (Fig. 6). 


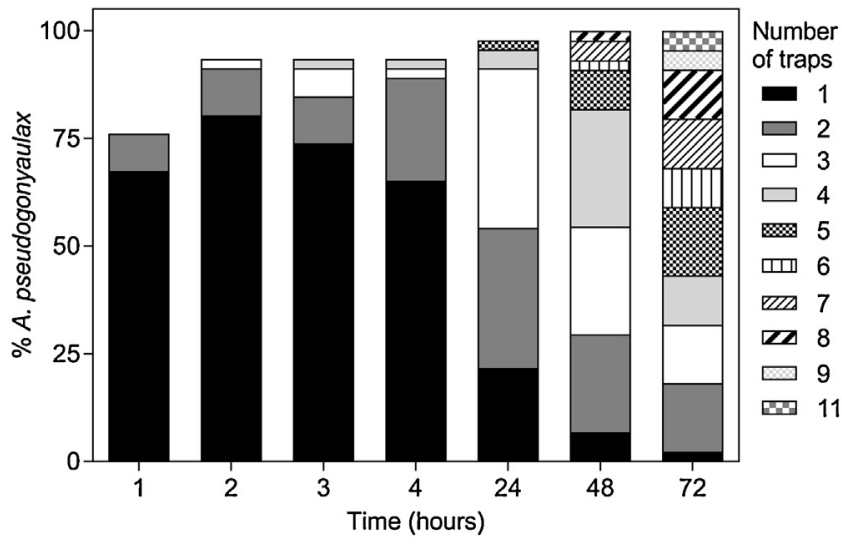

Fig. 5. Percentage A. pseudogonyaulax forming different numbers of traps at each time point. These results are taken from the experiment using strain K-1344 with $1 \times 10^{4}$ prey cells per well. Each pattern represents a certain number of traps formed, for example black bars represent the percentage of $A$. pseudogonyaulax that had formed 1 trap, dark grey bars represent the percentage of $A$. pseudogonyaulax that had formed 2 traps, etc. The total number of $A$. pseudogonyaulax was 46 , for the first $24 \mathrm{~h}$, and then at 48 and $72 \mathrm{~h}$ the total was 44 due to two individuals dying. The highest number of traps formed was 11 , and percentage $A$. pseudogonyaulax with 0 traps formed are not included in the bars.

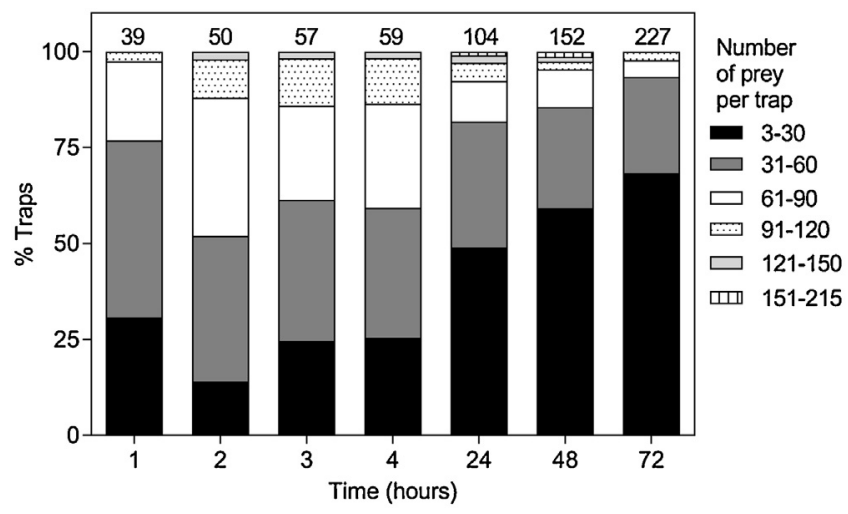

Fig. 6. Percentage of traps composed of a certain number of prey per trap. These results are taken from the experiment using strain K- 1344 with $1 \times 10^{4}$ prey cells per well. The traps were grouped in increments of 30 prey cells per trap except for traps containing greater than 150 cells. Each pattern represents a certain number of prey per trap, for example the black bars are the percentage of traps containing between 3 and 30 prey cells, etc. The total number of traps formed at each time point is written above each column.

The only characteristic investigated that did not depend on prey cell concentration was the size of the traps. Initially the traps exposed to less prey were slightly larger than the traps with high prey concentration, but after a few hours the average size of the traps decreased or remained the same over the course of the experiment (Fig. 4G and $\mathrm{H}$ ), and were similar in size regardless of prey concentration. The largest trap was observed after $4 \mathrm{~h}$ and measured $350 \mu \mathrm{m}$ (Fig. 7), but the majority of the traps were between 101 and $150 \mu \mathrm{m}$ (Fig. 7).

Within one hour, nearly $90 \%$ of all A. pseudogonyaulax that had produced a trap, were still attached to their trap. After $4 \mathrm{~h}$, the percentage of $A$. pseudogonyaulax attached to a trap started to decrease and reached $25 \%$ at $48 \mathrm{~h}$. After $48 \mathrm{~h}$, the number of $A$. pseudogonyaulax cells attached started to increase again. Cells first started to divide after $24 \mathrm{~h}$. Between 24 and $48 \mathrm{~h}, 17$ individuals (39\%) had divided and of those, only 1 was attached to a trap; the others were swimming around at a higher speed without forming traps yet. At $72 \mathrm{~h}, 33$ had divided (75\%) and 14 of these were attached. The decrease in number of attached cells alongside the

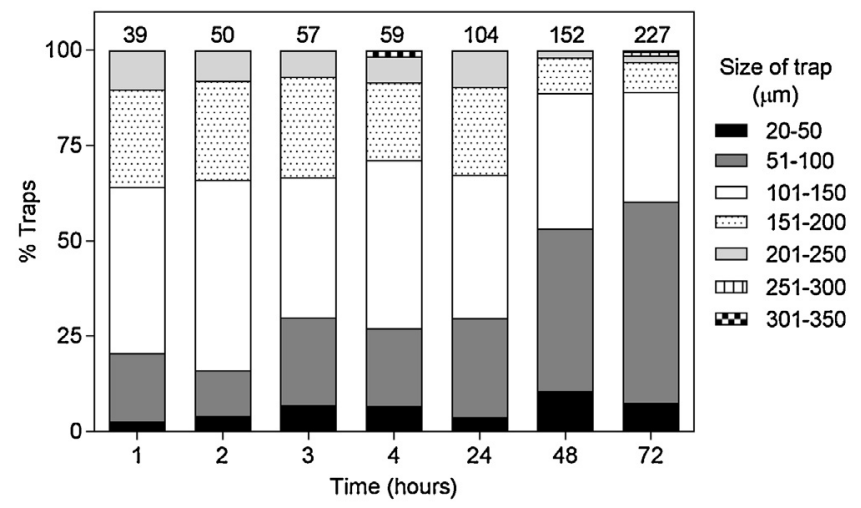

Fig. 7. Percentage of traps of a certain size category. These results are taken from the experiment using strain K-1344 with $1 \times 10^{4}$ prey cells per well. Each pattern represents a different size range listed in the legend. The total number of traps formed at each time point is written above each column.

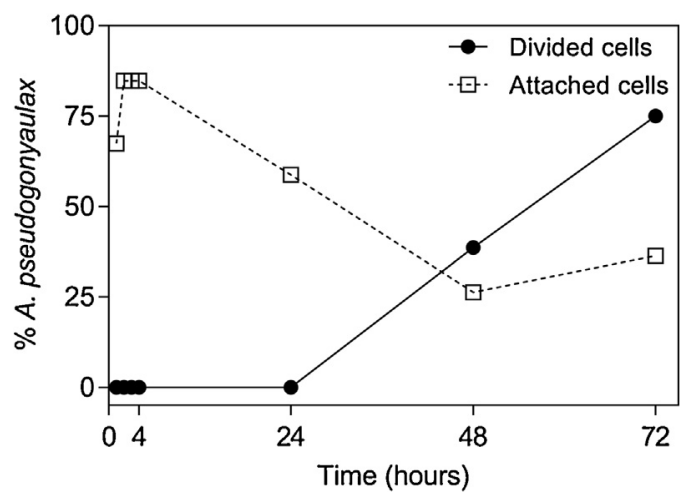

Fig. 8. Fraction of $A$. pseudogonyaulax cells of strain K- 1344 (with $1 \times 10^{4}$ prey cells) attached to a trap and percentage initial $A$. pseudogonyaulax cells that had divided. Percentage attached cells are represented by open squares and percentage cells that had divided during the incubation are represented by closed circles. The number of attached cells is related to all $A$. pseudogonyaulax cells, including those that had not formed a trap yet; this also includes the cells that had divided, so each of the 2 divided cells were included in the total (only applies to 48 and $72 \mathrm{~h}$ time points). For percentage divided cells, the total only includes the original number of $A$. pseudogonyaulax cells.

increase of the number of divided cells (Fig. 8) shows that cells that had just divided did not immediately form traps; after division, the cells continuously moved at an apparently faster (although not quantified) speed, and approximately within $24 \mathrm{~h}$ after division, they became stationary, and were forming and attached to their own trap again (Fig. 8).

Based on observations of $A$. pseudogonyaulax swimming behavior and movement when attached to a trap compared to in monoculture, it appears that there is also mucus formed when prey is absent. The cells attached to a trap are basically stationary and make a dragging motion; this same distinct movement was seen in the cells kept in monoculture almost to the same degree as those with prey present and visible traps. Therefore, A. pseudogonyaulax appears to form mucus even without prey present, although the extent of the mucus traps in monoculture could not be assessed with absolute certainty.

\subsection{Experiment 4. Fate of the prey cells caught in an abandoned mucus trap}

After the traps had been separated from both free-swimming prey cells, and the A. pseudogonyaulax cells, the percentage $H$. rotundata cells remaining decreased rapidly and went from $100 \%$ to 


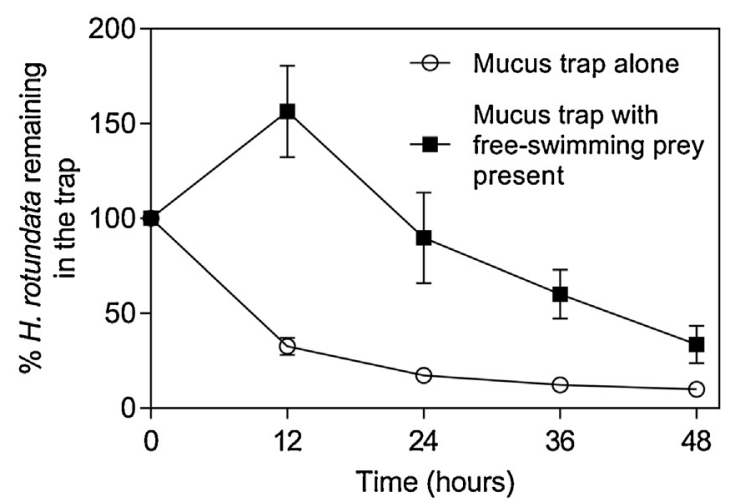

Fig. 9. The fraction of $H$. rotundata cells remaining in a mucus trap. The open circles show the prey in the mucus traps with no prey in the well while the closed squares show the prey in the mucus trap when free-swimming prey cells were present. Both are in the absence of the A. pseudogonyaulax cell. Points are averages (mucus trap alone $n=30$; with free-swimming prey present $n=33$ ). Error bars represent standard error of the mean.

$33 \%$ after $12 \mathrm{~h}$. After $24 \mathrm{~h}$ only $17 \%$ of the $H$. rotundata cells remained in the trap and after 36 and $48 \mathrm{~h} 12 \%$ and 10\% remained, respectively (Fig. 9). The initial amount of prey per trap varied greatly between traps and ranged between 7 and 57 with an average of 25 prey cells per trap. The number of visibly lysed cells when the mucus trap was left alone was quite low and the total amount of lysed $H$. rotundata cells in all the mucus traps combined did not exceed 12 out of a total of 739 cells. Even though this was only based on visibly lysed cells, the decrease of $H$. rotundata cells caught in the mucus did not appear to be a result of the cells lysing, but was because some of the $H$. rotundata cells were eventually able to escape the mucus, which was, in fact, observed several times during counting.

\subsection{Experiment 5. Ability of the abandoned mucus traps to catch prey}

After the removal of the A. pseudogonyaulax cells from the wells, the mucus traps were left with $100 \mathrm{H}$. rotundata cells freely swimming around in the wells. The prey therefore had the possibility to get stuck in the mucus traps if they encountered them. The mucus traps thus continued catching prey for $12 \mathrm{~h}$ and increased the number of prey with over $50 \%$, on average. There was a large range with some traps gaining cells and some losing them as the initial traps had between 3 and 19 prey cells per trap with an average initial size of 10 prey cells per trap. After the initial increase, the number of prey started to decrease as prey cells escaped. The decrease in prey was not as high as in the experiment where free-swimming prey was absent and thus would be attributed to recaptured cells indicating that the traps could continue catching prey for at least $48 \mathrm{~h}$ (Fig. 9).

\section{Discussion}

\subsection{Phagotrophy and mixotrophy in Alexandrium spp.}

In this screening of over 40 strains belonging to 8 different species of Alexandrium, phagotrophy was confirmed in 4 out of the 5 strains of $A$. pseudogonyaulax, and was not observed in any of the other species tested (Table 3). Phagotrophy of algae and/or bacteria has been documented in several species of Alexandrium: A. andersonii (Lee et al., 2016), A. catenella (Jeong et al., 2005a; Yoo et al., 2009), A. minutum (Jeong et al., 2005b), A. ostenfeldii (Gribble et al., 2005; Jacobsen and Anderson, 1996), A. pohangense (Lim et al., 2015), A. pseudogonyaulax (Jacobson, 1999; Blossom et al., 2012), and A. tamarense (Jeong et al., 2005a; Yoo et al., 2009).
Food vacuoles have been observed in situ in A. ostenfeldii (Jacobson and Anderson, 1996; Anderson et al., 2005; Gribble et al., 2005) and during feeding experiments in the other species (Jeong et al., 2005a,b; Yoo et al., 2009; Lim et al., 2015; Lee et al., 2016). Three of these species previously documented to ingest prey: A. tamarense, A. ostenfeldii, and A. catenella, were also tested in the current study; however no evidence of phagotrophy was observed. This discrepancy could be attributed to strain variation, however with the screening of 15 strains of $A$. tamarense and 19 strains of A. ostenfeldii from Greenland done here, a potential variability in phagotrophy among strains from the same location was accounted for. Time kept in laboratory culture may also influence feeding capabilities and the recent success of some studies, which use freshly isolated Alexandrium species, supports this (Lim et al., 2015; Lee et al., 2016). This was hopefully taken into account by using strains of $A$. ostenfeldii and $A$. tamarense that were only in culture for a few months prior to the beginning of the experiments (Table 1). The lack of phagotrophy in the present study could also be due to the type of prey species offered. Strong prey selection has been seen in other mixotrophic dinoflagellates, i.e. Dinophysis spp. feeding on red-pigmented Mesodinium spp. (Park et al., 2006) and Fragilidium subglobosum feeding on Ceratium spp. (Skovgaard, 1996; Hansen and Nielsen, 1997; Hansen et al., 2000; Skovgaard et al., 2000). Recent research supports this for Alexandrium as well, as $A$. pohangese only fed on Cochlodinium polykrikoides despite being offered 17 different prey species (Lim et al., 2015) and A. andersonii fed on only 3 out of 20 algal prey species offered (Lee et al., 2016). In contrast, food vacuoles of many different prey types have been observed in A. tamarense (Jeong et al., 2005a), and A. pseudogonyaulax can consume 6 different prey species Blossom et al., 2012 and the current study). At least 4 different prey species were offered here to select Alexandrium species (A. ostenfeldii, A. tamarense, and A. taylorii), including Rhodomonas salina, which Jeong et al. (2005a) successfully fed to A. tamarense, but here, none of these were consumed.

Another explanation for the lack of phagotrophy in this study could be because experiments were done with high $(\mathrm{f} / 2)$ nutrients and feeding might only be induced under nutrient limiting conditions. Many mixotrophic dinoflagellates, like A. pseudogonyaulax, take up prey irrespective of nutrient concentration (Hansen, 2011). Some species like Ceratium furca only ingest prey at low nutrient levels (Smalley et al., 2003), while in others, like Karlodinium veneficum, feeding increases during nutrient starvation (Li et al., 2000). In some of the successful feeding studies with Alexandrium spp. the nutrient levels were not reported, however cultures were diluted with local seawater prior to experiments and there could potentially be some kind of nutrient limitation occurring (Jeong et al., 2005a,b; Yoo et al., 2009; Lim et al., 2015; Lee et al., 2016). More nutrient limitation experiments with Alexandrium spp. should be done to attempt to induce feeding. To conclude, the lack of food uptake in the strains of $A$. catenella, $A$. ostenfeldii and $A$. tamarense used here does not necessarily mean they are not mixotrophic, but rather the optimal conditions to induce and promote phagotrophy were not found and/or the specific prey required was not offered.

In this study, the only Alexandrium species that ingested prey was A. pseudogonyaulax. The reason for this species' success in prey capture is likely the capability to produce a mucus trap, which in this study, was confirmed to be very non-specific in prey capture (Table 4). Not only could $A$. pseudogonyaulax catch many different species in the traps, but it was also able to ingest a wide variety of prey species. This study did not directly test for a prey preference, but theoretically, the A. pseudogonyaulax cell does have the possibility to choose prey cells, possibly of a higher nutritional value, and leave others caught in the trap. Perhaps this is why they are capable of capturing many more cells than they actually eat 
(see number of traps produced Figs. $4 \mathrm{~A}$ and $\mathrm{B}$ and 6 ). The average number of prey per trap reached approximately 60 (Fig. 4) and the maximum number of prey seen in one trap was 213 (Fig. 6) prey cells. This is much more than the extreme maximum of approximately 20 food vacuoles seen in one cell (personal observation). Furthermore, typically around $25 \%$ of cells will have food vacuoles, sometimes more (data not shown), but never $100 \%$, which is how many A. pseudogonyaulax were making traps in this study.

\subsection{Mucus production in the genus Alexandrium}

Mucus production is known for a number of phytoplankton species. Some species are embedded in a mucilaginous matrix such as the prymnesiophyte Phaeocystis spp. and species of the diatom genera Chaetoceros, Thalassiosira and Nitzschia (Margalef, 1997). Chaetoceros affinis produces mucus used for cell aggregation presumably to reduce cell losses from the euphotic zone (Kiørboe and Hansen, 1993). Aside from forming colonies or aggregates there may be various reasons that phytoplankton produce mucus such as density reduction, nutrient storage, or defense against grazers, among others (Reynolds, 2007); but there are relatively few examples of phytoplankton using mucus for prey capture. Noctiluca scintillans is one example of a dinoflagellate which uses a sticky mucus at the end of a capture filament to catch prey (Kiørboe and Titelman, 1998). Recently a mucus trap similar to that of A. pseudogonyaulax and used for prey capture of Mesodinium rubrum has been discovered in Dinophysis acuta (Ojamäe et al., 2016; Papiol et al., 2016), D. acuminata (Ojamäe et al., 2016), and D. cf. ovum (Mafra et al., 2016). This mucus trap produced by Dinophysis spp. differs from that produced by A. pseudogonyaulax in that it is not attached to the Dinophysis cell (Mafra et al., 2016). Because of a potentially close evolutionary relationship of species of Alexandrium it was hypothesized that the efficient mucus trap strategy of $A$. pseudogonyaulax could be realized by other species of the genus Alexandrium, particularly by other species of the subgenus Gessnerium. Surprisingly, the only other species investigated here to form some kind of mucus material was A. taylorii.

A. taylorii has the ability to form dense formations of mucus visible in both monoculture and mixed culture where most of the A. taylorii cells are attached by a mucus filament extruding from the sulcus area while the cell circles a larger mucus formation as if adding mucus to the construction. This production of mucus appears to be created by collaboration of many cells, perhaps to keep the cells together and avoid dispersal (Margalef, 1997) during blooms as suggested for diatom species (Kiørboe and Hansen 1993). Aggregations of cells, particularly cysts of $A$. taylorii have been seen before, although these were not necessarily associated with mucus (Garcés et al., 1998, 1999). Only a small amount of $H$. rotundata and $T$. acuta cells got stuck in the mucus; however, there was no evidence of ingestion, and prey capture is thus unlikely the purpose of mucus production by A. taylorii. Perhaps bacteria accumulating in the dense mucus constructions could function as prey for A. taylorii. Engulfment of bacteria was not tested for in the current study, but might be worthwhile to look into in the future to clarify the phagotrophic capabilities of $A$. taylorii.

\subsection{Mucus trap formation in A. pseudogonyaulax}

\subsubsection{Mucus trap formation, frequency, and maintenance over time}

Remarkably, $100 \%$ of the A. pseudogonyaulax cells formed traps when prey was abundant (Fig. 3). Not only did many of them form traps but the individual $A$. pseudogonyaulax cells produced a trap very quickly, with over $60 \%$ of the cells producing at least one trap after just one hour (Fig. 5). The seemingly immediate release of mucus when prey is present, and the fixed size of the traps regardless of prey concentration suggest that $A$. pseudogonyaulax responds quickly to the presence of prey, and is capable of releasing mucus at all times. It is also likely that $A$. pseudogonyaulax actually continually produces mucus, and the mucus is only visible as a "trap" as prey cells get caught in it. Observations of monocultures and preliminary experiments (done for another study, data not shown) on swimming behavior when prey is present versus in monoculture suggest that they actually do produce mucus in the absence of prey; it is just not visible, because thus far, there is no way to visualize the trap unless there is prey caught in it. If mucus is produced at all times, this could explain why traps are produced (or visible) so quickly.

The total amount of prey captured by one individual A. pseudogonyaulax increased with time and this coincided with an increase in the number of traps produced. It was not the size of the trap that continued to grow, but rather there was a maximum size of the traps, and the A. pseudogonyaulax rather makes a new trap than greatly increase the size of one trap (Figs. 4 and 7). This also means that the $A$. pseudogonyaulax cell repeatedly discards traps, just as it produces a new one which could be logical as a trap full of prey cells does appear to sink, and then the $A$. pseudogonyaulax cell could be dragged down through the water column, where at some point it would be limited by light for growth. The frequency with which these traps are produced and discarded was high and a large number of traps accumulated over time (Figs. 3 and 4). It is also possible that the high frequency of abandoned traps in this study is an artifact of the experimental design, because the traps seem to get stuck to the bottom of the wells, and it could be that the A. pseudogonyaulax cell abandons its trap after the trap gets stuck and cannot be moved anymore. Regardless, the repeated discarding of traps and formation of new ones supports the idea that the mucus is continually released.

\subsubsection{The attachment of the A. pseudogonyaulax cell to the mucus} trap

Throughout the experiment the number of traps with few prey cells increased with time (Fig. 6). A decrease of prey per trap may have various reasons; A. pseudogonyaulax cell engulfs the prey, prey cells may lyse, or prey cells actually have the means to escape the sticky mucus. The traps with only few cells in them were almost always traps with no $A$. pseudogonyaulax cell attached and, at every time point, the traps with the most prey cells in them, always had an A. pseudogonyaulax cell attached (data not shown), which suggests that the prey can escape when the A. pseudogonyaulax discards the trap and implies that in order to catch a lot of prey, the A. pseudogonyaulax cell should remain with its trap. It is probable that when attached, the $A$. pseudogonyaulax is actively releasing a toxin into the trap, making the trap much more efficient at catching and retaining other cells. After a certain time without the A. pseudogonyaulax cells attached, the released toxin, may diffuse away, allowing the $H$. rotundata cells to escape. It could also be that A. pseudogonyaulax uses the mucus trap to keep target cells in close proximity to released toxins. The toxin may accumulate in the mucus and toxin concentrations will remain effective before they are diluted by diffusion. This is the case for the toxins of the benthic dinoflagellate Ostreopsis cf. ovata which have also been shown to accumulate in the mucus released by this species (Giussani et al., 2015).

Interestingly, for several hours prior to cell division, the A. pseudogonyaulax cells were not attached to a trap and as cells divided after $48 \mathrm{~h}$ they did not form a mucus trap immediately. This behavior is evident (Fig. 8) where cells start to divide between 24 and $48 \mathrm{~h}$. At this time, the number of cells which are attached to a trap also declines (Fig. 8). After several hours, the new cells start to form their own mucus trap, which can be seen as the increase of attached cells. The fact that cells do not immediately form traps 
just before or after division perhaps indicates that resources need to be allocated towards division, rather than mucus trap production and that the newly divided cells have to accumulate energy before they are capable of producing a trap. For some of this time, between trap formations, the cells were encysted, as A. pseudogonyaulax forms immobile division cysts (Montresor, 1995); however they must not have been encysted for the entire $24 \mathrm{~h}$, because the division cysts were rarely seen during observations.

The nearly constant attachment to a trap by the A. pseudogonyaulax cell except before, after, and during cell division (observed when offered high prey concentration), along with the observations in monoculture described in Section 4.3.1 as well as the data presented here including the speed of which prey are caught in traps, and the fact that the size of the traps are the same regardless of prey concentration all suggests that mucus is continually released, independent of the presence of prey.

\subsubsection{Fate of the mucus trap and the prey caught within it}

The mucus trap of $A$. pseudogonyaulax continued catching prey for up to $48 \mathrm{~h}$ despite the absence of the predator. At the same time, prey cells escaped within the first $12 \mathrm{~h}$ after the trap was discarded (Fig. 9). It should be taken into account that $H$. rotundata was the only prey species used in this particular experiment and that it might have specific properties that enables it to escape the mucus trap such as its jump-like swimming behavior, or its higher resistance to allelochemicals (Blossom et al., 2012). Both the cryptophyte Teleaulax acuta and the ciliate Mesodinium rubrum have been shown to be more sensitive towards the toxic mucus trap of A. pseudogonyaulax and are more susceptible to cell lysis, compared to $H$. rotundata (Blossom et al., 2012). The effects of the trap on different prey organisms is likely variable and the amount of organic matter sinking out of the upper layer could be significantly larger than shown in this experiment. Although there are many processes in the natural environment that have not been addressed in these laboratory experiments, the mucus trap strategy may have a competitive component as a side effect, as unconsumed competitors of nutrients and light may be removed as well (Fistarol et al., 2004; Granéli and Hansen, 2006; Tillmann et al., 2008).

\section{Conclusions}

Phagotrophy may be common amongst Alexandrium spp., but it is a challenge to induce food uptake in the laboratory, despite a broad screening of a large number of species and strains by this and other studies. A mucus trap attached to the tip of the longitudinal flagellum and used for prey capture is, among Alexandrium species, still unique to $A$. pseudogonyaulax. In the experiments done here, individual behavior was presented, and although there was some variation, overall, there was a great amount of mucus production, with $100 \%$ of the cells in a given culture capable of producing mucus. The mucus traps will have a great impact on surrounding cells, as they remain sticky for up to $48 \mathrm{~h}$ after being abandoned, and could continue to capture other cells, despite no 'A. pseudogonyaulax cell attached. The evidence shown here suggests mucus release happens nearly at all times, although the extent to which this is dependent on presence of prey must be investigated further by visualizing the traps without prey present.

\section{Acknowledgements}

We thank the SCCAP, and its curator Gert Hansen, for supplying algal cultures. We are indebted to Dr. Antonella Penna, University of Urbino, Italy, who also kindly provided the A. taylorii strain. This study was supported by a PhD stipend from the Department of
Biology at the University of Copenhagen to Hannah Blossom and by the HABFISH project funded by the Innovation Fund, Denmark, Project Number 0603-00449B.[CG]

\section{References}

Anderson, D.M., Kulis, D.M., Keafer, B.A., Gribble, K.E., Marin, R., Scholin, C.A., 2005. Identification and enumeration of Alexandrium spp. from the Gulf of Maine using molecular probes. Deep Sea Res. (II Top. Stud. Oceanogr.) 52, 2467-2490. Anderson, D.M., Alpermann, T.J., Cembella, A.D., Collos, Y., Masseret, E., Montresor, M., 2012. The globally distributed genus Alexandrium: multifaceted roles in marine ecosystems and impacts on human health. Harmful Algae 14, 10-35.

Anderson, D.M., 1997. Bloom dynamics of toxic Alexandrium species in the northeastern US. Limnol. Oceanogr. 42, 1009-1022.

Anderson, D.M., 1998. Physiology and bloom dynamics of toxic Alexandrium species, with emphasis on life cycle transitions. In: Anderson, D.M., Cembella, A.D., Hallegraeff, G.M. (Eds.), Physiological Ecology of Harmful Algal Blooms. Springer-Verlag, Heidelberg, pp. 29-48.

Balech, E., 1995. The Genus Alexandrium Halim (Dinoflagellata). Sherkin Island Marine Station, Cork, Ireland.

Blossom, H.E., Daugbjerg, N., Hansen, P.J., 2012. Toxic mucus traps: a novel mechanism that mediates prey uptake in the mixotrophic dinoflagellate Alexandrium pseudogonyaulax. Harmful Algae 17, 40-53.

Burkholder, J.M., Glibert, P.M., Skelton, H.M., 2008. Mixotrophy, a major mode of nutrition for harmful algal species in eutrophic waters. Harmful Algae 8, 77-93.

Cembella, A., Lewis, N., Quilliam, M., 2000. The marine dinoflagellate Alexandrium ostenfeldii (Dinophyceae) as the causative organism of spirolide shellfish toxins. Phycologia 39, 67-74.

Fistarol, G.O., Legrand, C., Selander, E., Hummert, C., Stolte, W., Granéli, E., 2004. Allelopathy in Alexandrium spp.: effect on a natural plankton community and on algal monocultures. Aquat. Microb. Ecol. 35, 45-56.

Garcés, E., Delgado, M., Masó, M., Camp, J., 1998. Life history and in situ growth rates of Alexandrium taylori (Dinophyceae, Pyrrophyta). J. Phycol. 34, 880-887.

Garcés, E., Masó, M., Camp, J., 1999. A recurrent and localized dinoflagellate bloom in a Mediterranean beach. J. Plankton Res. 21, 2373-2391.

Giussani, V., Sbrana, F., Asnaghi, V., Vassalli, M., Faimali, M., Casabianca, S., Penna, A., Ciminiello, P., Dell'Aversano, C., Tartaglione, L., 2015. Active role of the mucilage in the toxicity mechanism of the harmful benthic dinoflagellate Ostreopsis cf. ovata. Harmful Algae 44, 46-53.

Granéli, E., Hansen, P.J., 2006. Allelopathy in harmful algae: a mechanism to compete for resources? In: Granéli, E., Turner, J.T. (Eds.), Ecology of Harmful Algae, , pp. 189-201.

Gribble, K.E., Keafer, B.A., Quilliam, M.A., Cembella, A.D., Kulis, D.M., Manahan, A., Anderson, D.M., 2005. Distribution and toxicity of Alexandrium ostenfeldii (Dinophyceae) in the Gulf of Maine: USA. Deep Sea Res. (II Top. Stud. Oceanogr.) 52, 2745-2763.

Hallegraeff, G.M., 1993. A review of harmful algal blooms and their apparent global increase. Phycologia 32, 79-99.

Hansen, P.J., Nielsen, T., 1997. Mixotrophic feeding of Fragilidium subglobosum (Dinophyceae) on three species of Ceratium: effects of prey concentration, prey species and light intensity. Mar. Ecol. Prog. Ser. 147, 187-196.

Hansen, P.J., Skovgaard, A., Glud, R.N., Stoecker, D.K., 2000. Physiology of the mixotrophic dinoflagellate Fragilidium subglobosum: II. Effects of time scale and prey concentration on photosynthetic performance. Mar. Ecol. Prog. Ser. 201, 137-146.

Hansen, P.J., 2011. The role of photosynthesis and food uptake for the growth of marine mixotrophic dinoflagellates. J. Eukaryot. Microbiol. 58, 203-214.

Hasle, G.R., Syvertsen, E.E., Steidinger, K.A., Tangen, K., Tomas, C.R., 1996. Identifying Marine Diatoms and Dinoflagellates. Academic Press.

Hsia, M.H., Morton, S.L., Smith, L.L., Beauchesne, K.R., Huncik, K.M., Moeller, P.D., 2006. Production of goniodomin A by the planktonic, chain-forming dinoflagellate Alexandrium monilatum (Howell) Balech isolated from the Gulf Coast of the United States. Harmful Algae 5, 290-299.

Jacobson, D.M., Anderson, D.M., 1996. Widespread phagocytosis of ciliates and other protists by marine mixotrophic and heterotrophic thecate dinoflagellates. J. Phycol. 32, 279-285.

Jacobson, D.M., 1999. A brief history of dinoflagellate feeding research. J. Eukaryot. Microbiol. 46, 376-381.

Jeong, H.J., Du Yoo, Y., Park, J.Y., Song, J.Y., Kim, S.T., Lee, S.H., Kim, K.Y., Yih, W.H., 2005a. Feeding by phototrophic red-tide dinoflagellates: five species newly revealed and six species previously known to be mixotrophic. Aquat. Microb. Ecol. 40, 133-150.

Jeong, H.J., Park, J.Y., Nho, J.H., Park, M.O., Ha, J.H., Seong, K.A., Jeng, C., Seong, C.N., Lee, K.Y. Yih, W.H., 2005b. Feeding by red-tide dinoflagellates on the cyanobacterium Synechococcus. Aquat. Microb. Ecol. 41, 131-143.

Kiørboe, T., Hansen, J.L., 1993. Phytoplankton aggregate formation: observations of patterns and mechanisms of cell sticking and the significance of exopolymeric material. J. Plankton Res. 15, 993-1018.

Kiørboe, T., Titelman, J., 1998. Feeding, prey selection and prey encounter mechanisms in the heterotrophic dinoflagellate Noctiluca scintillans. J. Plankton Res. 20, 1615-1636.

'Kirchner, M., Sahling, G., Uhlig, G., Gunkel, W., Klings, K.-W., 1996. Does the red tide-forming dinoflagellate Noctiluca scintillans feed on bacteria? Sarsia 81, 4555. 
Lee, K.H., Jeong, H.J., Kwon, J.E., Kang, H.C., Kim, J.H., Jang, S.H., Park, J.Y., Yoon, E.Y., Kim, J.S., 2016. Mixotrophic ability of the phototrophic dinoflagellates Alexandrium andersonii A. affine, and A. fraterculus. Harmful Algae 59, 67-81.

Li, A., Stoecker, D.K., Coats, D.W., 2000. Mixotrophy in Gyrodinium galatheanum (Dinophyceae): grazing responses to light intensity and inorganic nutrients. J. Phycol. 36, 33-45.

Lim, A.S., Jeong, H.J., Kim, J.H., Jang, S.H., Lee, M.J., Lee, K., 2015. Mixotrophy in the newly described dinoflagellate Alexandrium pohangense: a specialist for feeding on the fast-swimming ichthyotoxic dinoflagellate Cochlodinium polykrikoides. Harmful Algae 49, 10-18.

Mafra Jr, L.L., Nagai, S., Uchida, H., Tavares, C.P., Escobar, B.P., Suzuki, T., 2016. Harmful effects of Dinophysis to the ciliate Mesodinium rubrum: Implications for prey capture. Harmful Algae 59, 82-90.

Margalef, R., 1997. Turbulence and marine life. Sci. Marina 61, 109-123.

Montresor, M., 1995. The life history of Alexandrium pseudogonyaulax (Gonyaulacales, dinophyceae). Phycologia 34, 444-448.

Murakami, M., Makabe, K., Yamaguchi, K., Konosu, S., Wälchli, M.R., 1988. Goniodomin A, a novel polyether macrolide from the dinoflagellate Goniodoma pseudogoniaulax. Tetrahedron Lett. 29, 1149-1152.

Ojamäe, K., Hansen, P.J., Lips, I., 2016. Mass entrapment and lysis of Mesodinium rubrum cells in mucus threads observed in cultures with Dinophysis. Harmful Algae 55, 77-84.

Papiol, G.G., Beuzenberg, V., Selwood, A.I., MacKenzie, L., Packer, M.A., 2016. The use of a mucus trap by Dinophysis acuta for the capture of Mesodinium rubrum prey under culture conditions. Harmful Algae 58, 1-7.

Park, M.G., Kim, S., Kim, H.S., Myung, G., Kang, Y.G., Yih, W., 2006. First successful culture of the marine dinoflagellate Dinophysis acuminata. Aquat. Microb. Ecol. $45,101-106$.

Reynolds, C.S., 2007. Variability in the provision and function of mucilage in phytoplankton: facultative responses to the environment. Hydrobiologia 578, $37-45$.

Skovgaard, A., Hansen, P.J., Stoecker, D.K., 2000. Physiology of the mixotrophic dinoflagellate Fragilidium subglobosum: I. Effects of phagotrophy and irradiance on photosynthesis and carbon content. Mar. Ecol. Prog. Ser. 201, 129-136.
Skovgaard, A., 1996. Engulfment of Ceratium spp. (Dinophyceae) by the thecate photosynthetic dinoflagellate Fragilidium subglobosum. Phycologia 35, 490-499.

Smalley, G.W., Coats, D.W., Stoecker, D.K., 2003. Feeding in the mixotrophic dinoflagellate Ceratium furca is influenced by intracellular nutrient concentrations. Mar. Ecol. Prog. Ser. 262, 137-151.

Tillmann, U., Alpermann, T., John, U., Cembella, A., 2008. Allelochemical interactions and short-term effects of the dinoflagellate Alexandrium on selected photoautotrophic and heterotrophic protists. Harmful Algae 7, 52-64.

Tillmann, U., Kremp, A., Tahvanainen, P., Krock, B., 2014. Characterization of spirolide producing Alexandrium ostenfeldii (Dinophyceae) from the western Arctic. Harmful Algae 39, 259-270.

Tillmann, U., Krock, B., Alpermann, T.J., Cembella, A., 2016. Bioactive compounds of marine dinoflagellate isolates from western Greenland and their phylogenetic association within the genus Alexandrium. Harmful Algae 51, 67-80.

Triki, H.Z., Laabir, M., Moeller, P., Chomérat, N., Daly-Yahia, O.K., 2016. First report of goniodomin A production by the dinoflagellate Alexandrium pseudogonyaulax developing in southern Mediterranean (Bizerte Lagoon, Tunisia). Toxicon 111, 91-99.

Van Wagoner, R.M., Misner, I., Tomas, C.R., Wright, J.L., 2011. Occurrence of 12 methylgymnodimine in a spirolide-producing dinoflagellate Alexandrium peruvianum and the biogenetic implications. Tetrahedron Lett. 52, 4243-4246.

Yoo, Y.D., Jeong, H.J., Kim, M.S., Kang, N.S., Song, J.Y., Shin, W., Kim, K.Y., Lee, K., 2009. Feeding by phototrophic red-tide dinoflagellates on the ubiquitous marine diatom Skeletonema costatum. J. Eukaryot. Microbiol. 56, 413-420. 